\title{
Mortality Rate of Eodiaptomus japonicus (Copepoda: Calanoida) in Lake Biwa
}

\author{
Keiichi Kawabata
}

\begin{abstract}
Seasonal and ontogenetic changes in mortality rate were studied for Eodiaptomus japonicus in Lake Biwa during May to November from 1984 to 1986. Mortality rate during each sampling interval was determined for individuals born within a certain time interval by comparing the actual individual number on the latter sampling date with the number that would be expected in the absence of mortality. The present method differs from existing methods in following changes in the number of individuals through their development instead of confining itself to a fixed age class. Adult $E$. japonicus showed large mortality rates throughout the study period, while juveniles showed large values during May to July of both 1984 and 1985.
\end{abstract}

Key words: Planktonic copepod, mortality rate, estimation method, time- ${ }^{-}$and agedependency

\section{Introduction}

In analysing population dynamics, observed mortality rates are explained by certain lethal factors. When predation is the possible cause, the predation rate is compared with the mortality rate. Quantitative determination of mortality rates is therefore essential for population ecology. Furthermore, lethal factors usually change both seasonally and ontogenetically. Hence, the mortality estimation should be timeand age-dependent. Nevertheless, only a few studies have attempted to determine time- ${ }^{-}$and age-dependent mortality rates in zooplankter populations (see review in WOOD and NisBET, 1991). In the present study, I used a simple method to calculate the time- and age-dependent mortality rates of a calanoid copepod Eodiaptomus japonicus (BURCKHARDT) in Lake Biwa from published data. In subsequent papers I will study the lethal factors.

ManLy (1989) has classified stage-frequency data for stage-structured populations into the following three types by the occurrence of entries into the first stage: single cohort, all entries occur at the same time; multi-cohort, entries occur in the first part of the observation period; reproducing, entries occur throughout the observation period. The published data for E. japonicus in Lake Biwa (KawabATA, 1987) are reproducing stage-frequency data. Hence, several kinds of cohort analyses are not applicable in the present study. Besides, matrix approaches developed for the analysis of reproducing stage-frequency data are time- independent. In the present study, mortality rate during each sampling interval was determined for individuals born in a certain time interval by comparing the actual number on the latter sampling date with the number that would be expected in the absence of mortality. The latter number was predicted from their number on the former sampling date and their development times under the assumption of no mortality during the sampling interval.

\section{Methods}

KaWabata (1987) has reported seasonal changes in the abundance of each developmental stage of $E$. japonicus in the north basin 
of Lake Biwa. E. japonicus was collected at a fixed station approximately weekly during May to November from 1984 to 1986. Duplicate samples were collected with a 401 Schindler-Patalas trap at depth intervals of $2.5-5 \mathrm{~m}$. Samples were concentrated by filtration through a $40 \mu \mathrm{m}$ nylon netting and fixed in $6 \%$ formalin. After counting and staging, abundance in unit water column was calculated for each stage.

Instantaneous per capita mortality rate $\alpha$ can be calculated with the equation:

$$
\begin{aligned}
\alpha= & {\left[\operatorname{lnN}_{t}(a, b)\right.} \\
& \left.-\ln N_{t+\Delta t}(a+\Delta t, b+\Delta t)\right] \Delta t^{-1},
\end{aligned}
$$

where $\mathrm{N}_{t}(a, b)$ is the number of the individuals within the age range $a$ and $b(\mathrm{a}<\mathrm{b})$ at time $t$, and $\Delta t$ is the sampling interval. Thus $\mathrm{N}_{t}(a$, $b$ ) is the actual number on the former sampling date, and hence the expected number on the latter date; $\mathrm{N}_{t+\Delta t}(a+\Delta t, b+\Delta t)$, the actual number on the latter date.

Table 1 shows four age groups defined in the present study. The early age group consists of individuals that were in naupliar stages on the former date and had not yet moulted to copepodid stages on the latter date; the middle age group includes individuals that were in naupliar stages on the former date and had moulted to copepodid stages on the latter date; the late age group consists of individuals that were in copepodid stages on the former date and had not yet achieved adulthood on the latter date; and the adult group is made up of individuals that were adults on the latter date. The adult group is different from the other groups in that no individuals leave this group alive.

KaWABATA (1989) has measured the develop- ment times of $E$. japonicus using the natural food of Lake Biwa in 1986 and 1987. About ten individuals in a certain developmental stage were collected from Lake Biwa. Each of them was introduced into a $100 \mathrm{ml}$ Erlenmeyer flask with the lakewater filtered through a $40 \mu \mathrm{m}$ nylon netting. The stages of individuals were examined twice a day until they had moulted twice, thereby determining individual development times of each stage. Culture was performed near field temperatures under a 12:12 $\mathrm{h}$ LD cycle, and the water in the flasks was changed every day.

E. japonicus developed almost isochronally in naupliar stage II (NII) to copepodid stage IV (CIV). The same development times were hence used for NII to CIV in the present study. Besides, its development in NII to CV was scarcely affected by temperature between 15 and $25^{\circ} \mathrm{C}$ from May to October, but was delayed by some other factors in November. Mean development time in NI was $0.7 \mathrm{~d}$ at 15 and $20^{\circ}$ $\mathrm{C}$, and $0.4 \mathrm{~d}$ at $25^{\circ} \mathrm{C}$. Among 15,20 and $25^{\circ} \mathrm{C}$, the water temperature closest to that at the median depths of the population (KAWABATA, 1987) was used for the estimation of development times. For NII-CIV and CV, the mean development times measured for about ten individuals during each sampling interval were used when available. For the other sampling intervals, I used the following average develop. ment times measured during 1986 and 1987: for each of NII to CIV, $2.7 \mathrm{~d}$ (15 intervals, $\mathrm{SD}=0.7$ ) from May to October and $5.0 \mathrm{~d}(n=2)$ in November; for CV, $3.9 \mathrm{~d}(n=11, \mathrm{SD}=0.8)$ from May to October and $7.5 \mathrm{~d}$ in November $(n=2)$.

For sampling intervals when development times were measured, mortality rates were also

Table 1. Earliest and latest developmental stages of age groups on former and latter sampling dates. Stages shown as "nf" are not fixed.

\begin{tabular}{lccccc}
\hline & \multicolumn{2}{c}{ Former } & & \multicolumn{2}{c}{ Latter } \\
\cline { 2 - 3 } \cline { 5 - 6 } Age group & Earliest & Latest & & Earliest & Latest \\
\hline Early & $\mathrm{NI}$ & $\mathrm{nf}$ & & $\mathrm{nf}$ & $\mathrm{NVI}$ \\
Middle & $\mathrm{nf}$ & $\mathrm{NVI}$ & & $\mathrm{CI}$ & $\mathrm{nf}$ \\
Late & $\mathrm{CI}$ & $\mathrm{nf}$ & & $\mathrm{nf}$ & $\mathrm{CV}$ \\
Adult & $\mathrm{nf}$ & $\mathrm{CVI}$ & & $\mathrm{CVI}$ & $\mathrm{CVI}$ \\
\hline
\end{tabular}


calculated using the minimum and maximum development times measured during each interval for the early, middle and late age groups (data not shown). These mortality rates were similar to those calculated using mean development times, the ratio being $1.15 \pm 0.64$ (mean \pm $\mathrm{sD}, n=17)$ for the minimum values and $0.97 \pm$ $0.48(n=19)$ for the maximum values. Thus the use of mean development times scarcely biased mortality rates.

The age dividing two age groups was calculated from development times; for instance, the age dividing the early and middle age groups for 11-18 June 1984 was $7.2 \mathrm{~d}$ (1.1-d-old NIV) on 11 June and $14.2 \mathrm{~d}(0-\mathrm{d}-$ old $\mathrm{CI})$ on 18 June (Fig. 1). Thus individuals belonged to two age groups in four stages at most; NIV and CIII on both 11 and 18 June 1984 . The abundances of such stages were divided according to age, assuming uniform age distribution within a stage. In the above example, the abundance of NIV on 11 June was divided into 1.1/2.7 and 1.6/ 2.7 ( 2 and $3 \times 10^{4}$ individuals $\mathrm{m}^{-2}$ ) for the early and middle age groups, respectively.

When abundance on the former date is too small, the mortality rate obtained is unreliable. Hence, mortality rate was not calculated for the age group whose abundance on the former date was smaller than $1 \times 10^{5}$ individuals $\mathrm{m}^{-2}$. As a result, 75 out of 296 instances were excluded from the present calculation.

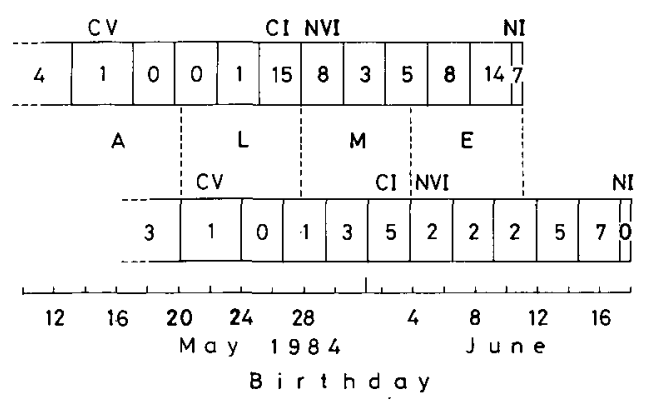

Fig. 1. Example of age-abundance distributions for Eodiaptomus japonicus developmental stages on 11 (upper) and 18 (lower) June 1984. Numbers show abundances $\left(10^{4}\right.$ individuals $\mathrm{m}^{-2}$ ); broken lines, boundaries of age groups (E, early; M, middle; L, late; A, adult).
Temporal differences in mortality rate were statistically examined by the Wilcoxon-MannWhitney test; and differences between age groups, by the Wilcoxon signed ranks test with a significance level of $1 \%$ (two-tailed test; Siegel and Castellan, 1988).

\section{Results}

Figures 2 and 3 show the seasonal changes in instantaneous per capita mortality rate for four age groups of E. japonicus in Lake Biwa. The mortality of the early age group was high throughout the study period, and particularly high during May to July of both 1984 and 1985. This group's mortality rate was larger than 0.2 $\mathrm{d}^{-1}$ in $40 \%$ of 20 sampling intervals during May- July of $1984-1985$, and in $9 \%$ of the other 44 intervals. The middle and late age groups also showed high mortality during May- July of 1984-1985. The proportion of mortality rates above $0.2 \mathrm{~d}^{-1}$ was $15 \% \quad(n=13)$ during the period and 7\% $(n=42)$ in the other intervals for the middle age group, and $56 \%(n=9)$ and $6 \%$ $(n=34)$, respectively, for the late age group. The mortality rate of the adult group was large throughout the study period, being larger than $0.2 \mathrm{~d}^{-1}$ in $15 \%$ of all 59 intervals.

The difference between May-July of 19841985 and the other intervals was significant for each of the early, middle and late age groups. For the entire study period, the early and late age groups showed larger mortality rates than the middle age group, and the adult group showed larger values than the middle and late age groups; each difference being significant.

\section{Discussion}

The annual instantaneous per capita mortality rates of the juvenile populations of diaptomid copepods in the field calculated from published life tables are as follows: 0.03 and 0.05 $\mathrm{d}^{-1}$ for Mixodiaptomus laciniatus and Skistodiaptomus oregonensis, respectively (RIGLER and Cooley, 1974); $0.05 \mathrm{~d}^{-1}$ for Diaptomus sanguineus (Hairston et al., 1983); and $0.22 \mathrm{~d}^{-1}$ for Diaptomus clavipes (GeHRS and RoBERTSON, 1975). The mortality rates of E. japonicus in Lake Biwa from May to July of both 1984 and 


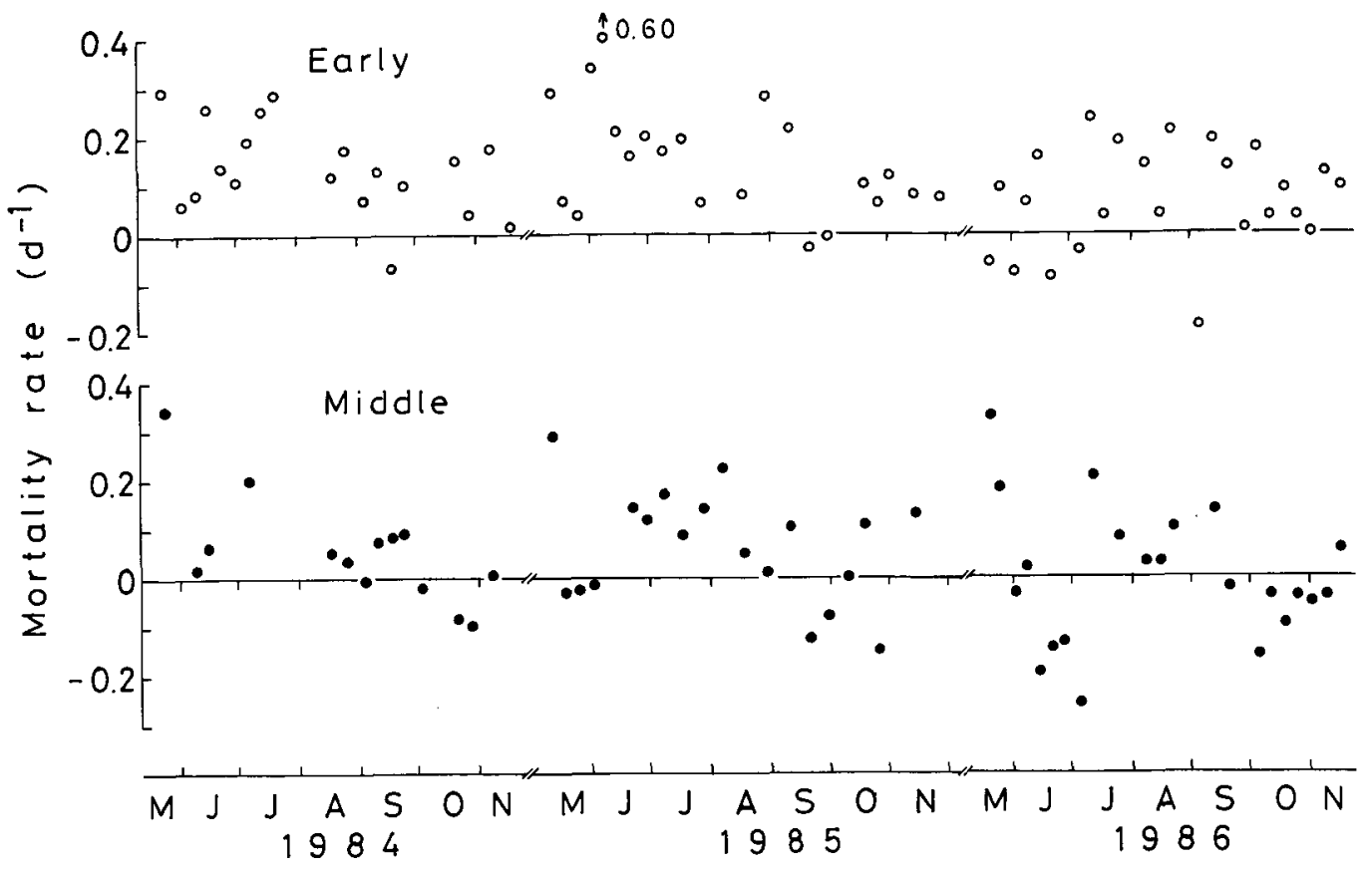

Fig. 2. Seasonal changes in instantaneous per capita mortality rate of Eodiaptomus japonicus for early and middle age groups. Symbols are plotted on median dates of sampling intervals.

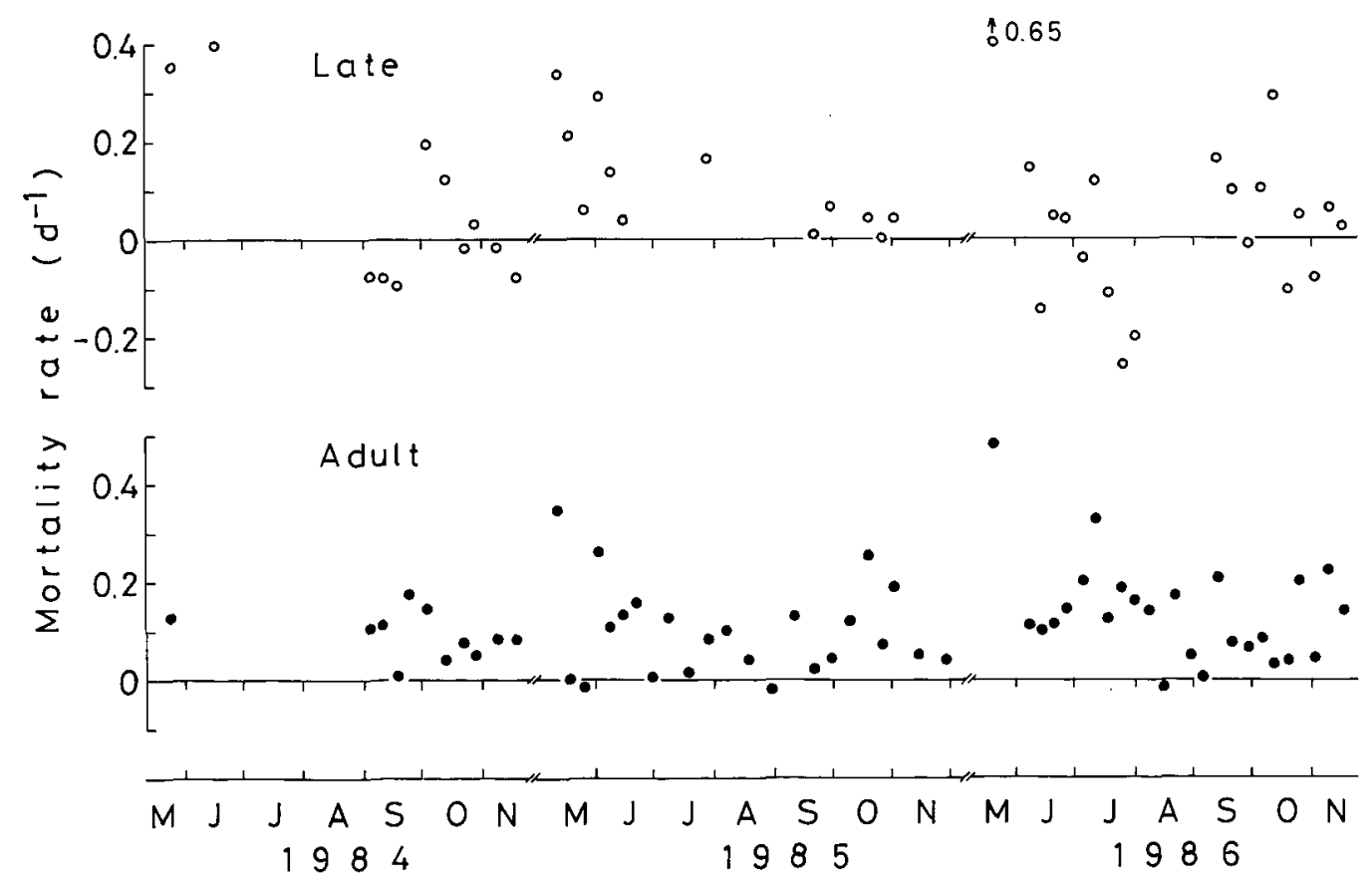

Fig. 3. As Fig. 2, but for late age and adult groups. 
Table 2. Example of abundances ( $10^{4}$ individuals $\left.\mathrm{m}^{-2}\right)$ of Eodiaptomus japonicus developmental stages on two successive dates in July 1986.

\begin{tabular}{lcccccccccccc}
\hline Date & NI & NII & NIII & NIV & NV & NVI & CI & CII & CIII & CIV & CV & CVI \\
\hline 1 July & 3 & 4 & 10 & 14 & 8 & 7 & 17 & 39 & 83 & 67 & 22 & 27 \\
8 July & 2 & 9 & 26 & 13 & 13 & 7 & 26 & 47 & 111 & 80 & 41 & 31 \\
\hline
\end{tabular}

1985 (see Figs. 2 and 3) were thus larger than the annual mortality rates of other diaptomid copepods except $D$. clavipes.

Comparing actual number and expected number in the absence of mortality, COOPER (1965) has calculated the time-dependent stage-specific mortality rates of a freshwater amphipod population in a lake. For zooplankter populations in the field, the following authors have estimated time-dependent mortality rates by comparing actual and expected numbers: Polishchuk and Ghilarov (1981), for the whole population of Diaphanosoma brachyurum; LyNCH (1983), for the size classes of four cladoceran species; HovenKamp (1989), for the size classes of two daphnid species; KING and GreENwood (1992), for the whole population of Boeckella minuta. Three authors have thus determined time-dependent, stage- or size-specific mortality rates; but HovenKamp (1989) provided no detailed calculations.

COOPER (1965), LynCH (1983) and the present study all followed the changes in number of individuals through their development. The former two authors regarded the mortality rate calculated for a sampling interval as that of the stage or size class on the latter sampling date, assuming that prerecruitment mortality is equal to that of the specific class. In the present study, rather than fixing classes, I defined age groups according to development during the interval. By a successive sampling regime, we can follow changes in the number of individuals developing through classes. It is therefore more straightforward to estimate mortality rates for developing individuals than for fixed classes.

The mortality rate of $E$. japonicus in Lake Biwa was negative in $21 \%$ of all 221 instances (see Figs. 2 and 3). For the sampling intervals when development times were measured and used for mortality estimation, the proportion of negative values was $27 \%(n=26)$. Thus the use of average development times measured in 1986 and 1987 did not raise the proportion of negative values. CoOPER (1965) reported that $26 \%$ of all 54 mortality rates calculated were negative; PolishchuK and Ghilarov (1981), 48\% $(n=29)$; Lynch $(1983), 22 \% \quad(n=69)$. The present proportion of negative values $21 \%$ is lower than theirs.

Negative mortality is obtained when abundance is either underestimated on the former date or overestimated on the latter date. Table 2 shows such an extreme example. The large abundance of CIII on 8 July 1986 cannot be explained by normal recruitment from the earlier stages. PolishchuK and Ghilarov (1981) suggested horizontal migration as the cause of negative mortality. Although KaWABATA (1987) did not find horizontal migrations for E. japonicus in Lake Biwa, spatial heterogeneity in its distribution may be the error source. COOPER (1965) and LYNCH (1983) attributed negative mortality rates to sampling error. Accurate sampling is therefore crucial in mortality estimation.

\section{Acknowledgements}

I am grateful to Drs T. NARITA, E. HARADA, M. Nagoshi, Y. Tezuka and Y. Yoshida, and two anonymous reviewers for comments on the manuscript. I also wish to thank researchers of Otsu Hydrobiological Station for discussions.

\section{摘要}

Eodiaptomus japonicus (カイアシ亜綱, カラヌ ス目）の琵琶湖における死亡速度

1984 年から 3 年間の 5 月から 11 月にかけての, 琵琶湖におけるEodiaptomus japonicus の死亡速 度の季節的変化および発育にともなう変化を調べ 
た。各採集間隔における死亡速度は，ある時間間 隔に生まれた個体の集団について，第二の採集日 に扔ける実際の個体数と死亡がないときに期待さ れる個体数を比較して求めた。本方法は, 既存の 方法のように固定した令階級を考慮するのではな く, 発育してゆく個体の数の変化を追うものであ る。成体のE.japonicus は全期間を通じて大きな 死亡速度を示したが，未成熟個体は 1984 年と 1985 年の 5 月から 7 月の間に大きな値を示した。

\section{References}

COOPER, W. E. (1965): Dynamics and production of a natural population of a fresh-water amphipod, Hyalella azteca. Ecol. Monogr., 35: 377394.

GeHrs, C. W. and A. Robertson (1975): Use of life tables in analyzing the dynamics of copepod populations. Ecology, 56: 665-672.

Hairston, N. G., Jr., W. E. Walton and K. T. L I (1983): The causes and consequences of sexspecific mortality in a freshwater copepod. Limnol. Oceanogr., 28: 935-947.

Hovenkamp, W. (1989): Instar-dependent mortality rates of coexisting Daphnia species in Lake Vechten, The Netherlands. J. Plankton Res., 11, 487-502.

KaWABaTA, K. (1987): Abundance and distribution of Eodiaptomus japonicus (Copepoda: Calanoida) in Lake Biwa. Bull. Plankton Soc. Japan, 34: 173-183.

KaWABATA, K. (1989): Natural development time of Eodiaptomus japonicus (Copepoda: Calanoida) in Lake Biwa. J. Plankton Res., 11: 1261-1272.

KInG, C. R. and J. G. Greenwood (1992): The seasonal population changes and carbon budget of the calanoid copepod Boeckella minuta Sars in a newly formed sub-tropical reservoir. J. Plank. ton Res., 14: 329-342.

Lynch, M. (1983): Estimation of size-specific mortality rates in zooplankton populations by periodic sampling. Limnol. Oceanogr., 28: 533545.

MANLY, B. F. J. (1989): A review of methods for the analysis of stage-frequency data, p. 3-69. In L. L. MCDONaLd, B. F. J. ManLY, J. A. LOCKWOOD and J. A. LogAN (eds.), Estimation and analysis of insect populations. Springer Verlag.

Polishchuk, L. V. and A. M. Ghilarov (1981): Comparison of two approaches used to calculate zooplankton mortality. Limnol. Oceanogr. 26: 1162-1168

Rigler, F. H. and J. M. Cooley (1974): The use of field data to derive population statistics of multivoltine copepods. Limnol. Oceanogr., 19: 636-655.

Siegel, S. and N. J. Castellan Jr. (1988): Nonparametric statistics for the behavioral sciences, 2nd ed. McGraw-Hill.

WooD, S. N. and R. M. NisBET (1991): Estimation of mortality rates in stage-structured population. Springer Verlag.

(著者:川憣佳一, 京都大学大津臨湖実験所，現所 属: 金沢大学教育学部生物学教室, $\bar{\top} 920-11$ 金沢市 角間町; Keiichi KawaBATA, Otsu Hydrobiological Station, Kyoto University; Present address: Depart. ment of Biology, Faculty of Education, Kanazawa University, Kakuma-machi, Kanazawa 920-11)

Received: 1 October 1992

Accepted: 10 February 1993 